\title{
Practical- Skill among Institutionalised Children
}

\author{
Dr. Rita Rani Talukdar, Hemasri K. Talukdar \\ (Head, Department of Psychology, Gauhati University) \\ (Assistant Professor, Department of Psychology, Karmashree Hiteswar Saikia College)
}

\begin{abstract}
In the present study an attempt was made to study the practical skills among institutionalized children in greater Guwahati area. The sample consisted of 100 students (50 male and 50 female) taken from various institutions situated in Guwahati, the capital of Assam state. For this study Pass Along Test by Alexander was used. Their age ranges between the age group of 9 to 11 years. In this study the practical skill of the male students are found to be high than their female counterparts.
\end{abstract}

Key words: Guwahati, Institutionalised children, practical-skill

\section{Introduction:}

The term 'Skill' was originally used with respect to motor activity. It may be defined as proficiency, facility or dexterity that is acquired or developed through training and experience. It is the capacity for carrying out complex, well-organized patterns of behaviour smoothly and adaptively so as to achieve some end or goal.

Practical skills, which can be defined as doing skills or the ability of an individual to perform and apply things learnt in theory or acquired theoretically and put them to practice in the field or in various situation, what have learned in real life situation and in work.

The term "institution" is commonly applied to customs and behaviour patterns important to a society as well as to particular formal organizations of government and public services. As structures and mechanisms of social order among humans, institutions are one of the principal objects of study in the social sciences, such as political science, anthropology, economics and sociology (the latter being described by Durkheim as the "science of institutions, their genesis and their functioning"). Institutions are also a central concern for law, the formal mechanism for political rule-making and enforcement.

Institutionalization is the placing of children in institutions outside the home. Institutionalization refers to the process of embedding something within an organization, social system or society as a whole. The term may also be used to refer to committing a particular individual or group to an institution, such as mental or welfare institution. An institution is any structure or mechanism of social order and cooperation governing the behaviour of a set of individuals within a given community. Institutions are identified with a social purpose and permanence, transcending individual human lives and intensions and with the making and enforcing of rules governing cooperative human behaviour.

\subsection{Objectives of the study:-}

a) To study the practical skill of institutionalized children.

b) To compare the practical skill of institutionalized male and female children.

\subsection{Hypothesis:}

There will be no significant difference in terms of practical skill among the male and female institutionalized children.

\subsection{Methodology:}

1.4.1 Sample:

The total sample size is 100 . The 100 subjects have been classified as 50 male and 50 female who were selected randomly using purposive sampling technique from Greater Guwahati area of Assam state. Their age ranges between the age group of 9 to 11 years.

\subsubsection{Tools used for Data Collection:}

For collecting the data to study the practical skill of the institutionalized children the Pass Along Test developed by Alexander was administered. 


\subsubsection{General Description of the Pass Along Test:}

The test comprises nine boxes, each containing a number of small blocks, one of which (in two cases) is coloured red, while the others are coloured blue. One end of the box is red and the other blue and the problem in each case is to move the red end of the box without lifting the blocks out of the box, but by moving them within the limited space left in the box. The blocks have all a definite size relationship, and the combination of blocks varies in each box. As a result, the problem varies in difficulty and the aim has been make the complexity of the task increase as we go through the series. The first box presents a problem which is simple for the average five years old, while the last box is sufficiently difficult to test superior adult intelligence. The boxes have been so arranged that each is preparation for the next. In this way the test measures the subject's ability to profit by experience as well as measuring the insight with which he reacts to a novel situation.

\section{Statistics Employed:}

In this study Mean, Standard Deviation and t-test were computed to find out the practical skill of institutionalized children.

\subsection{Procedure of Data Collection:}

In the present study, the investigator visited a number of Children's Home, Orphanage Home, State Home and Snehalaya in the greater Guwahati area of the Assam State. For collection of the data the Pass Along Test was administered among the subjects. Prior to the actual administration of the test, a rapport was established with the subject. Then, the subject was instructed according to the instructions laid down by the author of the test. Ascertaining that, the subject is clear about the instructions, the actual test was conducted one by one. Finally, the responses of the subject were recorded in the response sheet and subjected for further proceeding.

\subsection{Result and Discussion:-}

The present study intended to search the practical skill of institutionalized children.

Table 1

Scores of Pass Along Test

\begin{tabular}{|l|l|}
\hline $\mathrm{N}$ & 100 \\
\hline Sum & 9916 \\
\hline Mean & 99.16 \\
\hline S.D & 13.18 \\
\hline
\end{tabular}
respectively.

The data in the Table 1 indicate that the mean value and S.D of institutional children is 95.86 and 13.18

Table 2

Category wise Scores on Pass Along Test

\begin{tabular}{|l|l|l|l|l|l|}
\hline Category & $\mathrm{N}$ & Sum & Mean & Standard Deviation & t value \\
\hline Male & 50 & 5032 & 100.64 & 12.73 & \multirow{2}{*}{1.28} \\
\hline Female & 50 & 4884 & 97.68 & 13.26 & 1.28 \\
\hline
\end{tabular}

The Table 2 shows the category wise scores on Pass Along Test. The data in the Table shows that the male subjects in the institutional group obtain high score than the female subjects. The mean value of institutional male children and institutional female children are 100.64 and 97.68 respectively. The S.D of institutional male children is 12.73 and that of female children is 13.26. It shows that the practical skill is found to be high in case of institutional male children than their female counterparts.

The computed value of $t$, i.e. 1.28 is quite smaller than the critical table value 1.98 and hence is not significant. Therefore, the null hypothesis cannot be rejected and as a result, there is a significant difference in terms of practical skill among the male and female institutionalized children in 5\% level of significance

\section{Conclusion:-}

From the above discussion it is clear that the practical skill of male children is slightly higher than the female children. There is a significant difference in the practical skill of institutionalized male and female children. 


\section{References:}

[1]. Baron R.A (1995): "Psychology: The Essential Science", New York: Allyn \& Baoen.

[2]. Mangal, S.K:"Statistics in Psychology and Education", PHI Learning Pvt. Ltd.

[3]. Fernandes, M.M: “The Advanced Educational Psychology", The Psychology of the Learner, Himalaya Publishing House.

[4]. Garret, E. Henry (1981):"Statistics in Psychology and Education” David Mckay Company Inc. New York.

[5]. Hilgard, E.R, Atkinson, R.C \& Atkinson R.I. "Introduction to Psychology", Oxford \& IBH Pub Co. Pvt. Ltd., New Delhi.

[6]. Lefton, L.A. (1985): "Psychology", Boston; Allyn \& Bacon.

[7]. Mehta, P. \& Mathur R.(1986): 'A Multivariate study of some cognitive abilities and Academic achievement of First generation Learners'. Indian Journal of Psychometry and Education. 17 (1).

[8]. Minimum, E.W, King,B.M \& Bear, G (1993) 'Statistical Reasoning in Psychology and Education', New York: john Wiley.

[9]. Morgan, C.T, Richard A, King, Weisz, J \& Scopler, J: 'Introduction to Psychology' Mcgraw- Hill International editions.

[10]. Morgan \& King (1986): 'Introduction to Psychology', Mcgraw Hill.

[11]. Michael W. Eysencki: ‘The Black well Dictionary of Psychology’(Edited) 